\title{
DOES TOURISM SECTOR MATTER IN REGIONAL ECONOMIC DEVELOPMENT
}

\author{
Lorentino Togar LAUT \\ Tidar University, Faculty of Economic, Magelang, Indonesia, e-mail: lorentino@untidar.ac.id \\ Rr. Retno SUGIHARTI* \\ Tidar University, Faculty of Economic, Magelang, Indonesia, e-mail: retno.sugiharti@untidar.ac.id \\ Jihad Lukis PANJAWA \\ Tidar University, Faculty of Economic, Magelang, Indonesia, e-mail: jipanjawa@untidar.ac.id
}

\begin{abstract}
Citation: Laut, L.T., Sugiharti, R.R., \& Panjawa, J.L. (2021). DOES TOURISM SECTOR MATTER IN REGIONAL ECONOMIC DEVELOPMENT. GeoJournal of Tourism and Geosites, 37(3), 832-837. https://doi.org/10.30892/gtg.37313-715
\end{abstract}

\begin{abstract}
The regional autonomy policy is expected to promote the government in carrying out fiscal management independently. However, local own-source revenue was the only source of revenue and measurement of independence and it has not been achieved optimally. Many provinces failed to fully support regional needs, even though it has the highest tourism sector revenue contributors. The purpose of this study is to analyze the influence of the tourism sector in terms of supply and demand on regional independence. To analyze the regional income model seen from the contribution of the tourism sector by including the lag variable, this study used a Dynamic Panel method which is also known as Partial Adjusted in Central Java Province, Indonesia from 2013-2018. The result showed that the increase in local own-source revenue from the demand side is more elastic than the supply contribution. The addition of new tourist objects without proper management tends not to have a significant impact on regional income. Also, the attraction of people visiting the tourist in Central Java Province is still high because of a significant positive number of tourist arrivals. The government needs to focus on managerial improvements, development, and innovation of existing tourist objects
\end{abstract}

Key words: regional growth, tourism, decentralization, local own source revenue.

$* * * * * *$

\section{INTRODUCTION}

In recent decades, the rapid growth of the tourism plays an important role by increasing the industrial sectors and regional economies (Dwyer et al., 2003; Eadington and Redman, 1991; Lin et al., 2019; Milne and Ateljevic, 2001; Yang and Fik, 2014). The central government of Indonesia implemented the regional autonomy system on January 1, 2001 to regulate the economy and maximize tourism potential in the regions. Moreover, this regional autonomy system was regulated in Law No. 22 of 1999 and also subjected to Law No. 23 of 2014. Therefore, the enactment of this law makes the local governments to have freedom in government, self-government, and community affairs. These regions are capable of financing and managing their need because of the existence of decentralization. Furthermore, the stipulation of autonomy helps the regional government to maximizes the aid policy because of the full understanding of their territory (Ridwan et al., 2020). However, the regional government are expected to determine the level of dependence on the central government in relation to revenues and expenditures. The total regional revenue that consists of local own source revenue, balancing funds, loans, and other legal revenue is the main revenue for local government.

Regional independence can be measured from the amount of local own-source revenue and balancing funds received. Therefore, the Central Java is one of the provinces that are quite good at encouraging local own-source revenue. This can be seen from the value of local own-source revenue that is greater than the balancing funds received because its share with balanced funds is not consistent. Theoretically, if the local own-source revenue trend is up, then the balancing fund should go down because an increase in local own-source revenue indicates that regional financial independence is also increasing. Table 1 shows the comparison of local own-source revenue and balancing fund for Central Java Province 2012-2019. Table 1 shows that the local own-source revenue of Central Java Province has a good increasing trend even though it is fluctuating. The trend of balance funds received is very volatile and shows no signs of a downward trend. Therefore, the government needs to encourage local own-source revenue most especially through sectors that have the potential of having a high contribution to it. The tourism sector is one of the sources of Local ownsource revenue that recently shown a good increase. According to Canh and Thanh (2020); Eric et al. (2020); Lee et al. (2020); Yergeau (2020); Zadeh Bazargani and Kiliç (2021), the tourism sector help in reducing the economic vulnerability. Therefore, the tourism sector has become an interesting topic for researchers and policy makers to evaluate the impact of the sector and understand the drivers of its performance over time and across countries and regions. This has attracted a great deal of interest in empirical investigations of the tourism-driven growth hypothesis,

\footnotetext{
* Corresponding author
} 
such as that of Aktymbayeva et al. (2020); Belloumi (2010); Roudi et al. (2019); Tugcu (2014). The tourism does not necessarily increase income and welfare if it is not capable of implementing policies.

Moreover, Sheng (2011) used the combination of general and partial equilibrium analysis to obtained the result that the combined policy tools are based on tourism taxes and subsidizes non-tourism at a destination and unsuitable for tourist purposes thereby having a negative impact on local welfare. The increase in the growth of the tourism sector yearly brings a development to the economy of Central Java province. The growth in the output of the food and beverage accommodation supply reached $19.4 \%$ yearly even though the contribution of the tourism sector to total GDP is stagnant in the range of 3\% (Indonesian Central Burau of Statistics, 2018), Meanwhile, the stretching of tourism in the province of Central Java when viewed from the input side can be seen in the development of the number of hotel buildings by $22.27 \%$ from 2016 to 2018 , and $7.22 \%$ in 2018 to 2019 . This data is shown in Table 2.

Table 1. Development of local own-source revenue and Central Java Province Balancing Fund 2012-2019 (Sources: Indonesian Central Burau of Statistics, 2019)

\begin{tabular}{|c|c|c|c|}
\hline \multirow[t]{2}{*}{ Year } & \multirow{2}{*}{$\begin{array}{l}\text { Local own-source } \\
\text { revenue }\end{array}$} & \multirow{2}{*}{$\begin{array}{l}\text { Balancing } \\
\text { Funds }\end{array}$} & Growth (\%) \\
\hline & & & Local own-source revenue \\
\hline 2012 & $6,629,308.01$ & $2,318,806.10$ & \\
\hline 2013 & $8,212,800.64$ & $2,467,814.63$ & $23.89 \%$ \\
\hline 2014 & $9,916,358.23$ & $2,542,626.75$ & $20.74 \%$ \\
\hline 2015 & $10,904,882.04$ & $2,257,142.99$ & $9.97 \%$ \\
\hline 2016 & $11,541,029.72$ & $8,017,297.60$ & $5.83 \%$ \\
\hline 2017 & $12,547,513.39$ & $11,067,786.49$ & $8.72 \%$ \\
\hline 2018 & $13,711,732.77$ & $10,933,776.83$ & $9.28 \%$ \\
\hline 2019 & $14,112,159.00$ & $11,787,397.00$ & $2.92 \%$ \\
\hline
\end{tabular}

Table 2. Development of the Number of Hotels and Other Accommodations in Central Java Province 2016 - 2019 (Source: Indonesian Central Burau of Statistics, 2019)

\begin{tabular}{|c|c|c|c|}
\hline & $\mathbf{2 0 1 6}$ & $\mathbf{2 0 1 8}$ & $\mathbf{2 0 1 9}$ \\
\hline Hotel 1 Star & 56 & 60 & 11 \\
\hline Hotel 2 Star & 56 & 81 & 52 \\
\hline Hotel 3 Star & 84 & 91 & 101 \\
\hline Hotel 4 Star & 34 & 48 & 85 \\
\hline Hotel 5 Star & 8 & 11 & 63 \\
\hline Other accommodation & 1374 & 1715 & 1752 \\
\hline
\end{tabular}

The highest increase in the number of hotels was at 5-star, which implies that stretching economic activity and investment in Central Java Province has increased. However, the Central Java Province received the 2019 GOLD Indonesia Attractiveness Award in the Tourism sector because it was considered to have an excellent tourism attractiveness and potential development in the future (Tribun Jateng, 2019). This prompt the government to encourage tourist attraction both nationally and internationally, most especially with the existence of Borobudur as a leading tourism icon in Indonesia.

There is lack of evidence on the role of the tourism sector in terms of its effects in the short and long term on local revenue. Furthermore, the universality and broader application of previous studies was difficult and even impossible thereby leading to biased conclusions and wrong choices about policy measures to develop the tourism sector. This study contributes in identifying the role of the tourism sector on local revenue both in the short- and long-term conditions that was accompanied by control variables. Furthermore, several tourism indicators help in providing a permanent option for increasing local revenue. This study re-examines the role of the tourism sector in contributing to Local own-source revenue in the Central Java Province. The research question to be answered is the amount of elasticity of the tourism needed both in terms of input and output to contribute to local own-source revenue.

Several studies have analyzed the contribution of the tourism sector to local own-source revenue. The study of Mardianis and Syartika (2018), examined the contribution of the tourism sector to local revenue by taking research objects in Kerinci district. The purpose of this study is to examine the tourism sector in Kerinci as the leading one that is expected to have an economic impact on local own-source revenue. This study used the Quotient, Dynamic Location Quotient, and Specialization Index and SWOT method to analyzed the sector development strategies. The results showed that the tourism sector is yet to be leading and the proposed development strategy is focused on increasing the uniqueness of Kerinci as a tourist destination. This is done through the development of tourist areas based on community participation, fostering tourism-conscious people, and diversifying of tourism products that can become regional characteristics compared to other regions. Furthermore, the fostering of a tourism awareness movement "tradition of going home / returning home", help in preserving local culture as unique tourism and increasing promotion and publication.

The study of Wulandari and Ardyan (2018) examined the amount of contribution that can be made by the tourism industry sector of the City of Surabaya to their regional revenue through tourist variables, vehicles parked at tourist attractions, and room occupancy rates. The results of this study indicate the variables that have a positive effect, and they include the number of tourists, the government capable of issuing policies that expand tourism, and occupancy rates in the room and city of Surabaya. The purpose of the study of Ulhusna et al. (2017) was to find out the role of the number of tourist objects, number of tourists and the occupancy rate of hotels on the regional revenue of the City of Bukittinggi. Also, Sutrisno (2013) examined how these three variables affect the tourism levies of districts and cities in Central Java. The results showed that the object variables, the number of hotels and the GRDP had a positive and significant effect on retribution revenues. Furthermore, some research discussed the relationship between tourism and regional growth (Garrigós-Simón et al., 2015; Lionetti and Gonzalez, 2012; Budiharseno, 2017; Liu et al., 2017; Surugiu and Surugiu, 2013), also the study of Li et al. (2015), Lau et al. (2017), and Shi et al. (2007) used dynamic method to analyze tourism sector with Regional Origin Revenue.

Previous study has reported contribution tourism to regional growth in various result, however, there are still few studies exploring dynamic panel models in regions that implement regional autonomy. Previous study that analyzed the influence of the tourism sector with local own-source revenue as dependent variable was limited to static models. As goes in Indonesia, there are still a few studies in Indonesia that analyzed it, and using dynamic method, also consider that local own-source revenue is highly dependent on economic conditions at time $t$. 
The government usually take time in implementing policy to set its local own-source revenue achievement and the issue of taking time was ignored by previous study and assumed to be constant. The hypothesis that will be tested in this study conducts to prove the relationship between variables. First, Indonesia has the opportunity to sell its natural scenery and cultural attractions to foreign and domestic tourists who are willing to enjoy them, especially support by geographical conditions. The tourist resorts are one of the areas that are physical and more comfortable having the capacity of attracting tourists, however, the water tourism business help in organizing tourism and water sports that includes the provision of facilities and infrastructure and other services for commercial management in sea, beaches, rivers, lakes and reservoirs (Sánchez-Rivero et al., 2020; Shen et al., 2020). Therefore, the arrival of tourists tends to increase the income of the areas they visit, while the arrival of foreign tourists increases the income of the country's foreign exchange. Then the hypothesis to be tested is:

H1: The object variables (attract) have a positive relationship and significant effect on the local own-source revenue (OLGR) of districts and cities in Central Java Province.

According to Leiper (1990), tourists have a positive economic impact, starting with foreign exchange income, tourism business income, employment, improving the balance of foreign trade, and passing government revenue that must be taxed (Botti et al., 2008). Logically speaking, the more tourists, the longer the stay, and the amount of money to be spent will be determined by ones needs during the trip. The income of the owner of the tourism is affected by a number of consumer activities thereby making taxation and distribution to be increased in the future. However, the taxation and distribution are part of the original income and they include hotels, restaurants, and parking fees etc. Then the hypothesis to be tested:

H2: The variable number of tourists have a positive relationship and significant effect on the local own-source revenue (OLGR) of Districts and Cities in Central Java Province.

Furthermore, the hotel occupancy rates indicate the amount of tourist visits to certain areas and the increase in the hotel occupancy rate gives room for the development of attractiveness of an area. Then the hypothesis to be tested:

H3: Hotel occupancy rates (HOR) have a positive relationship and significant effect on district and local own-source revenue (OLGR) in Central Java Province.

The number of restaurants built and provided help in supporting tourism (Paci and Marrocu, 2014). This is because restaurants provide food and places for the public to eat and charge certain food and service fees. The establishment of restaurants benefit the manager through the profits made from sales and the tourists by meeting their needs (Gajic, 2015). Also, if the number of restaurants increases, income tax will have a positive impact on the development of local income in the tourism industry. Then the hypothesis to be tested is:

H4: The variable number of restaurants (Resto) have a positive relationship and significant effect on local own-source revenue $(O L G R)$ in districts and cities in Central Java province.

The control variables help in preventing a biased calculation results and the one used were GRDB and total population. Furthermore, it helps in complimenting or controlling the causal relationship to make it easy to get a complete and better empirical method. The control variables are used to control the relationship between the independent and dependent variables, because it has an effect on the independent variable and also give room for GRDB to have a partial and significant effect on local own-source revenue. This study explained that GRDB with a positive value assumes that districts and cities in Central Java Province increases by the distribution of trade, hotels, and restaurants. These are the types of business fields that provide the largest contribution to GRDP thereby developing the region economy. Then the hypothesis to be tested:

H5: Variable GRDP (GDP) have a positive relationship and significant effect on the local own-source revenue (OLGR) of Regions and Cities in Central Java Province.

The population of a particular cities and regions also has a relationship with local revenue. Therefore, developing countries such as Indonesia that experience a population explosion will always make a connection between population and economic development. The relationship between the two depends on the nature and population problems faced by each country. Furthermore, each country or region have its own unique population problems, potentials, and challenges. The increase in population will have both a positive and negative effect on local revenue. Then the variables that will be tested are:

H6: Variable Total population (pop) have a positive relationship and significant effect on the local own-source revenue (OLGR) of districts and cities in Central Java Province.

\section{MATERIALS AND METHODS}

This study used a deductive method for positivism perspective which explained how researchers begin relationships that are logically derived from causal laws in general theory. Therefore, all these processes lead to empirical testing and legal confirmation (theory) in social life. In general, deductive method are used for positivism perspective thereby helping in developing and asserting a theory that begins with abstract concepts and theoretical relationships which leads to more concrete empirical evidence (Neuman, 2011). This study obtained a panel data from Indonesian Central Bureau of Statistics to cover the districts and cities in the Central Java from 2013-2018. The main focused of this study is Central Java District Culture and Tourism Office and the Ministry of Tourism. Furthermore, this study used a historical 
data thereby making a linear regression method to be carried out with the addition of the time variable. This study used a dynamic method which is known as Partial Adjustment to accommodate time lag. Therefore, from the hypotheses that have been compiled above, an empirical method was estimated as follows:

$R O I=f($ attract, hor, resto, tourist, grdb, pop $)$

In which:

OLGR : Regional Original Income

Attract : Number of Attractions

HOR : Hotel Occupancy Rate

Resto : Number of restaurants

Tourist : Number of Tourists

GRDB : Gross Regional Domestic Product

Pop : Total Population

Change to econometrics equation, Eq. 1 written as:

$R O I_{\text {it }}=\beta_{0}+\beta_{1}$ attract $_{\text {it }}+\beta_{2}$ hor $_{\text {it }}+\beta_{3}$ resto $_{\text {it }}+\beta_{4}$ tourist $_{\text {it }}+\beta_{5}$ GDRB $_{\text {it }}+\beta_{6}$ Pop $_{\text {it }}+\varepsilon_{\text {it }}$

The adaptive expectation model is written as follows:

$R O I_{\text {it }}=\delta R O I_{\text {it }}^{*}+(1-\delta) R O I_{\text {it }-1}$

Substitute equation 2 to equation 3 ,

$$
\begin{aligned}
& R O I_{\text {it }}=\delta\left(\beta_{0}+\beta_{1} \text { attract }_{\text {it }}+\beta_{2} \text { hor it }_{\text {it }}+\beta_{\mathrm{a}} \text { resto }_{\text {it }}+\beta_{4} \text { tourist }_{\text {it }}+\beta_{5} G R D B_{\text {it }}+\beta_{6} \text { Pop }_{\text {it }}+\varepsilon_{\text {it }}\right)+(1-\delta) R O I_{\text {it }-1} \\
& R O I_{\text {it }}=\delta \beta_{0}+\delta \beta_{1} \text { attract }_{\text {it }}+\delta \beta_{2} \text { hor }_{\text {it }}+\delta \beta_{3} \text { resto }_{\text {it }}+\delta \beta_{4} \text { tourist }_{\text {it }}+\delta \beta_{5} G R D B_{\text {it }}+\delta \beta_{6} P_{0 p_{i t}}+\delta \varepsilon_{\text {it }}+(1- \\
& \text { Б) } P A D_{\text {it }-1} \\
& R O i_{i t}=\alpha_{0}+\alpha_{1} \text { attract }_{\text {it }}+\alpha_{2} \text { hor it }_{\text {it }}+\alpha_{2} \text { resto }_{\text {it }}+\alpha_{4} \text { tourist }_{\text {it }}+\alpha_{5} \text { GDRB }_{\text {it }}+\alpha_{6} \text { Pop }_{\text {it }}+\alpha_{7} R O I_{\text {it }-1}+v_{\text {it }}
\end{aligned}
$$

This study used a static and dynamic panel regression method and also used Random Effect Model (REM) to estimate the model. This is because, this study focused on the characteristic of dependent variable in term of analyzing the relationship between determiner to local own-source revenue (OLGR) as dependent variable. Furthermore, the test of Hausman and LM was used to select the best variable between Fixed Effect and Random Effect Model.

\section{RESULTS AND DISCUSSION}

Table 3 shows the descriptive statistic of the variable that was used, while Table 4 shows the estimation result for Static panel regression to compare static and dynamic method. The standard deviation of all variables is high, which indicates that the deviation of each variable is relatively high.

Table 3. Result for Descriptive Statistics

\begin{tabular}{|c|c|c|c|c|c|}
\hline Variable & Obs & Mean & Std. Dev. & Min & Max \\
\hline OLGR & 210 & $2.79 \mathrm{E}+08$ & $2.11 \mathrm{E}+08$ & $3.97 \mathrm{E}+07$ & $1.79 \mathrm{E}+09$ \\
\hline GRDB & 210 & $2.37 \mathrm{E}+07$ & $2.22 \mathrm{E}+07$ & 4755092 & $1.31 \mathrm{E}+08$ \\
\hline Population & 210 & 968233 & 411692.5 & 119879 & 1802829 \\
\hline Attract & 210 & 14.2381 & 9.14113 & 2 & 39 \\
\hline HOR & 210 & 34.27995 & 10.38396 & 14.39 & 73.37 \\
\hline Resto & 210 & 81.84286 & 104.4661 & 0 & 844 \\
\hline Tourist & 209 & 1323694 & 2645502 & 28702 & $2.88 \mathrm{E}+07$ \\
\hline OLGR_lag1 & 209 & $2.79 \mathrm{E}+08$ & $2.11 \mathrm{E}+08$ & $3.97 \mathrm{E}+07$ & $1.79 \mathrm{E}+09$ \\
\hline
\end{tabular}

Table 5. Model Selection

\begin{tabular}{|c|c|c|}
\hline & AIC & BIC \\
\hline Static Panel regression & 8414.001 & 8437.397 \\
\hline Dynamic Panel regression & 8072.243 & 8095.639 \\
\hline
\end{tabular}

Table 6. Selection of panel regression models

\begin{tabular}{|c|c|c|c|}
\hline Test & Statistic test & Result & Kesimpulan \\
\hline \multirow{2}{*}{ Hausman test } & chi2(4) & 1.4 & \multirow{2}{*}{ Random Effect } \\
\cline { 2 - 3 } & Prob>chi2 & 0.8438 & \\
\hline $\begin{array}{c}\text { Breusch and Pagan Lagrangian } \\
\text { multiplier test for random effects }\end{array}$ & chibar2(01) & 144.04 & \multirow{2}{*}{ Random Effect } \\
\cline { 2 - 3 } & Prob > chibar2 & 0.00000 & \\
\hline
\end{tabular}

Table 4. Estimation result for Static panel regression

\begin{tabular}{|l|l|l|l|}
\hline & $(1)$ & $(2)$ & $(3)$ \\
\hline & OLS & Fixed & Random \\
\hline attract & -993416.3 & -1178659.8 & 962458.9 \\
\hline & $(1402986.2)$ & $(2010638.9)$ & $(1917747.4)$ \\
\hline \hline HOR & $3122720.8^{* * * *}$ & 781286.3 & 498787.4 \\
\hline & $(913384.8)$ & $(734275.9)$ & $(853794.3)$ \\
\hline \hline resto & $300782.9^{* * * *}$ & 23066.8 & $173847.4^{* *}$ \\
\hline & $(95313.5)$ & $(75426.9)$ & $(87065.2)$ \\
\hline \hline tourist & 5.181 & $-6.327^{* * * *}$ & $-5.619^{* * *}$ \\
\hline & $(3.649)$ & $(2.168)$ & $(2.600)$ \\
\hline \hline GRDP & $6.174^{* * * *}$ & $13.46^{* * * *}$ & $10.01^{* * * *}$ \\
\hline & $(0.656)$ & $(3.356)$ & $(1.153)$ \\
\hline \hline pop & 37.73 & $2269.5^{* * * *}$ & -40.82 \\
\hline & $(27.20)$ & $(686.1)$ & $(60.14)$ \\
\hline \hline cons & -28387203.6 & $-2.24020 \mathrm{e}+09^{* * * *}$ & 43601795.3 \\
\hline & $(42544357.8)$ & $(589291920.3)$ & $(63266150.7)$ \\
\hline$N$ & 209 & 209 & 209 \\
\hline
\end{tabular}

Standard errors in parentheses ${ }^{*} p<0.1,{ }^{* *} p<0.05,{ }^{* * * *} p<0.01$

The comparison between the AIC and BIC values was used to choose either static or dynamic method as the best. This is shown by the smallest values of Akaike information criterion (AIC) and Bayesian information criterion (BIC). The AIC and BIC values in Table 5 shows that a Dynamic Panel Regression method is better than the Static Panel regression. The calculation was continued by: firstly, conducting the Hausman test to determine whether the Random Effect is better than the Fixed Effect Model. Secondly, conducting the Breusch and Pagan Lagrangian Multiplier test to determine whether Random Effect is better than Common Effect Model. The result is shown in Table 6. 
Table 7. Dynamic panel regression output

\begin{tabular}{|c|c|c|c|}
\hline & (1) & (2) & (3) \\
\hline & OLS & Fixed & Random \\
\hline \multirow[t]{2}{*}{ attract } & -703065.3 & -1417820.9 & 151704.7 \\
\hline & (1253351.2) & (2012227.2) & $(1627602.1)$ \\
\hline \multirow[t]{2}{*}{ HOR } & $2761101.7^{\pi /}$ & 578800.7 & $1765253.5^{N .}$ \\
\hline & $(814441.1)$ & $(743164.8)$ & (870208.6) \\
\hline \multirow[t]{2}{*}{ resto } & $275869.0^{m}$ & 4478.8 & 260890.1 \\
\hline & $(85001.5)$ & (76131.7) & (88284.6) \\
\hline \multirow[t]{2}{*}{ tourist } & 1.956 & $-6.094^{2.2 m}$ & -3.485 \\
\hline & (3.276) & $(2.172)$ & (2.861) \\
\hline \multirow[t]{2}{*}{ GRDP } & $4.625^{\circ}$ & $15.66^{* a t}$ & $6.307^{* w a}$ \\
\hline & $(0.654)$ & $(3.674)$ & $(0.872)$ \\
\hline \multirow[t]{2}{*}{ pop } & $46.29^{\prime \prime}$ & $2135.0^{*}$ & 21.02 \\
\hline & $(24.23)$ & $(699.0)$ & $(36.67)$ \\
\hline \multirow[t]{2}{*}{ OLGR_lag1 } & $0.317^{* \cdots+}$ & -0.0543 & $0.154^{4 \cdots}$ \\
\hline & $(0.0480)$ & $(0.0335)$ & $(0.0419)$ \\
\hline \multirow[t]{2}{*}{ _cons } & $-72428218.8^{*}$ & $-2.12396 \mathrm{e}+09$ & -12576918.3 \\
\hline & $(38495923.9)$ & $(596795776.1)$ & (47920469.4) \\
\hline$N$ & 208 & 208 & 208 \\
\hline
\end{tabular}

From the Hausman Test, it can be concluded that the $\mathrm{P}$ Value (Prob> Chi2) is <Alpha 0.05 thereby making H1 to be rejected. This means that the best model to use is the Random Effect compared to the Fixed Effect. Meanwhile, the test of Breusch and Pagan Lagrangian multiplier concluded that $\mathrm{p}$ value (Prob> Chibar2) is $<$ Alpha 0.05 thereby making $\mathrm{H} 1$ to be accepted. This means that the best model to use is Random Effect compared to Common Effect Model.The result on dynamic panel estimation shows that two of the four variables in the tourism sector, which are Hotel Occupancy (HOR) and the number of restaurants (RESTO) has significant effect on local own-source revenue (OLGR). The development of hotel occupancy and the number of restaurants can increase local acceptance. Therefore, hotels and restaurants have a role as drivers of regional development, they need to be developed properly to increase OLGR. Also, hotel is one type of business that provides services for the public and tourists. Hotel occupancy rate is a condition to what extent the number of rooms is sold when compared to the availability and adequate rooms that can be

sold because tourists are not reluctant to visit an area. This condition makes the tourists to feel safer and more comfortable to stay longer in the tourist area. Therefore, the tourism industry, most especially activities related to lodging tends to get more and more income. The object variables and the number of tourists show that the proxies of the tourism sector have no significant effect. This means that the number of tourist visits does not have a significant effect on local revenue. The number of tourist objects has not been optimal in its management both in terms of facilities and infrastructure. Furthermore, tourist objects fail to affect local revenue because there is lack of development and promotion that are not good. Also, the program for developing tourist objects causes tourists to be less interested in coming to these attractions. The development of the hotel and restaurant trading business tends to lead to an increase in GDP (Gross Regional Domestic Product). However, this in turn increase the local taxes which affect the local government revenue (OLGR) for Regencies and Cities in Central Java Province. The results are consistent with the study of Sutrisno (2013) which states that GRDB has an influence on local Government Revenue (OLGR).

The results prove that the tourism industry has the potential to increase regional income. The cooperation between governments through the tourism and culture with the private sector and the community needs to be well built in developing and maintaining the sustainability of the tourism industry. Therefore, the government together with the private sector and the community needs to continue innovating and providing breakthroughs to increase the attractiveness or potential of the region. The government provides training and assistance to managers and small-medium enterprise of the tourism sector to increase skills and opportunities. Hotels and restaurants were innovated by providing a tour packages to increase the demand for both domestic and foreign tourists. Also, the innovation helps in providing a clear information for tourists thereby leading to the increase in visits and occupancy by tourists which in turn increases regional income.

\section{CONCLUSION}

The result showed that gross regional domestic product has a significant positive effect on local revenue. The result demonstrates that changes in the number of hotel occupants and restaurants plays an important role in the tourism industry thereby leading to the increase of local income. Also, to increase local income, it is necessary to consider the control effect of regional GDP on regional economic performance. Therefore, the government must play its role with the support of the private sector and society in managing the tourism to increase public and private revenues.

The increase in gross regional domestic product as an indicator of economic performance measurement help in developing local government revenue through taxes and levies. This also encourages the improvement of local government services to the community which are expected to increase their productivity and economic activity. Meanwhile, the population has not been able to have a significant effect on local revenue. This indicates that there are several residents who have below taxable income to contribute to the increase in local revenue. Further study is suggested to examine other dimensions of tourism such as the level of tourist expenditure with a more complex method that is able to analyze in short and long terms for current dynamic conditions.

\section{REFERENCES}

Aktymbayeva, A., Assipova, Z., Moldagaliyeva, A., Nuruly, Y., \& Koshim, A. (2020). Impact of small and medium-sized tourism firms on employment in Kazakhstan. GeoJournal of Tourism and Geosites, 32(4), 1238-1243. https://doi 10.30892/gtg.32407-563

Belloumi, M. (2010). The relationship between tourism receipts, real effective exchange rate and economic growth in Tunisia. International Journal of Tourism Research, 12(5), 550-560. https://doi.org/https://doi.org/10.1002/jtr.774

Botti, L., Peypoch, N., \& Solonandrasana, B. (2008). Time and tourism attraction. Tourism Management, 29(3), 594-596. https://doi.org/10.1016/j.tourman.2007.02.011

Budiharseno, R.S. (2017). Factors affecting online buying behavior on g-market site among international students in Busan: A qualitative research. Arthatama, 1(1), 1-5. https://arthatamajournal.co.id/index.php/home/article/view/4/1 
Canh, N.P., \& Thanh, S.D. (2020). Domestic tourism spending and economic vulnerability. Annals of Tourism Research, 85(August), 103063. https://doi.org/10.1016/j.annals.2020.103063

Dwyer, L., Forsyth, P., \& Spurr, R. (2003). Inter-industry effects of tourism growth: Implications for destination managers. Tourism Economics, 9(2), 117-132. https://doi.org/10.5367/000000003101298303

Eadington, W.R., \& Redman, M. (1991). Economics and tourism. Annals of Tourism Research, 18(1), 41-56. https://doi.org/ 10.1016/0160-7383(91)90038-D

Eric, T.N., Semeyutin, A., \& Hubbard, N. (2020). Effects of enhanced air connectivity on the Kenyan tourism industry and their likely welfare implications. Tourism Management, 78(July 2019), 104033. https://doi.org/10.1016/j.tourman.2019.104033

Gajic, M. (2015). Gastronomic Tourism - a Way of Tourism in Growth. Quaestus, 6, 155-166.

Garrigós- Simón, F.J., Galdón-Salvador, J.L., \& Gil-Pechuán, I. (2015). The economic sustainability of tourism growth through leakage calculation. Tourism Economics, 21(4), 721-739. https://doi.org/http://dx.doi.org/10.5367/te.2014.0372

Lau, P.L., Koo, T.T., \& Dwyer, L. (2017). Metrics to measure the geographic characteristics of tourism markets: An integrated approach based on Gini index decomposition. Tourism Management, 59, 171-181. https://doi.org/10.1016/j.tourman.2016.07.019

Lee, Y.J.A., Kim, J., Jang, S., Ash, K., \& Yang, E. (2020). Tourism and economic resilience. Annals of Tourism Research, July 2019, 103024. https://doi.org/10.1016/j.annals.2020.103024

Li, H., Goh, C., Zhang Qiu, H., \& Meng, F. (2015). Effect of tourism on balanced regional development: A dynamic panel data analysis in Coastal and Inland China. Asia Pacific Journal of Tourism Research, 20(6), 694-713. https://doi.org/10.1080/10941665.2014.930055

Lin, V.S., Yang, Y., \& Li, G. (2019). Where Can Tourism-Led Growth and Economy-Driven Tourism Growth Occur? Journal of Travel Research, 58(5), 760-773. https://doi.org/10.1177/0047287518773919

Lionetti, S., \& Gonzalez, O. (2012). On the relationship between tourism and growth in Latin America. Tourism and Hospitality Research, 12(1), 15-24. https://doi.org/10.1177/1467358411429635

Liu, J., Nijkamp, P., \& Lin, D. (2017). Urban-rural imbalance and Tourism-Led Growth in China. Annals of Tourism Research, 64, 2436. https://doi.org/10.1016/j.annals.2017.02.005

Mardianis, M., \& Syartika, H. (2018). Kontribusi Sektor Pariwisata terhadap Pendapatan Asli Daerah di Kabupaten Kerinci. Jurnal Ekonomi \& Kebijakan Publik, 09(1), 53-65. https://doi.org/10.22212/jekp.v9i1.972

Milne, S., \& Ateljevic, I. (2001). Tourism, economic development and the global-local nexus: Theory embracing complexity. Tourism Geographies, 3(4), 369-393. https://doi.org/10.1080/146166800110070478

Neuman, W.L. (2011). Social Research Methods: Qualitative and Quantitative Approaches. USA: Allyn and Bacon

Paci, R., \& Marrocu, E. (2014). Tourism and regional growth in Europe. Papers in Regional Science, 93(S1), S25-S50. https://doi.org/10.1111/pirs.12085

Ridwan, R., Rahmat, Y., \& Aly, M.N. (2020). Tourism Development Planning In Bantaeng District, South Sulawesi. International Journal of Psychosocial Rehabilitation, 24(09), 326-334. https://doi.org/10.37200/IJPR/V24I9/PR290316

Roudi, S., Arasli, H., \& Akadiri, S.S. (2019). New insights into an old issue-examining the influence of tourism on economic growth: evidence from selected small island developing states. Current Issues in Tourism, 22(11), 1280-1300. https://doi.org/ 10.1080/13683500.2018.1431207

Sánchez-Rivero, M., Rodríguez-Rangel, M.C., \& Fernández-Torres, Y. (2020). The identification of factors determining the probability of practicing Inland water tourism through logistic regression models: The case of Extremadura, Spain. Water (Switzerland), 12(6), 1-22. https://doi.org/10.3390/W12061664

Shen, C.C., Liang, C.F., Hsu, C.H., Chien, J.H., \& Lin, H.H. (2020). Research on the impact of tourism development on the sustainable development of reservoir headwater area using china's tingxi reservoir as an example. Water (Switzerland), 12(12), 1-19. https://doi.org/10.3390/w12123311

Sheng, L. (2011). Taxing tourism and subsidizing non-tourism: A welfare-enhancing solution to "Dutch disease"? Tourism Management, 32(5), 1223-1228. https://doi.org/10.1016/j.tourman.2010.09.009

Shi, C., Zhang, J., Yang, Y., \& Zhou, Z. (2007). Shift-share analysis on international tourism competitiveness-A case of Jiangsu Province. Chinese Geographical Science, 17(2), 173-178. https://doi.org/10.1007/s11769-007-0173-2

Surugiu, C., \& Surugiu, M.R. (2013). Is the tourism sector supportive of economic growth? Empirical evidence on Romanian tourism. Tourism Economics, 19(1), 115-132. https://doi.org/10.5367/te.2013.0196

Sutrisno, D.C. (2013). Pengaruh Jumlah Obyek Wisata, Jumlah Hotel, Dan Pdrb Terhadap Retribusi Pariwisata Kabupaten / Kota Di Jawa Tengah. Economics Development Analysis Journal, 2(4), 435-445. https://doi.org/10.15294/edaj.v2i4.3211

Tugcu, C.T. (2014). Tourism and economic growth nexus revisited: A panel causality analysis for the case of the Mediterranean Region. Tourism Management, 42, 207-212. https://doi.org/10.1016/j.tourman.2013.12.007

Ulhusna, R., Harlen, \& Taryono. (2017). Pengaruh Sub Sektor Pariwisata Terhadap Pendapatan Asli Daerah (PAD) Kota Bukittinggi. JOM Fekon, 4(1), 445-459. https://jom.unri.ac.id/index.php/jomfekon/article/view/12679/12321

Wulandari, N.F, \& Ardyan, P.S. (2018). Analisis Pengaruh Jumlah Wisatawan, Kendaraan Yang Parkir Di Tempat Wisata Dan Tingkat Hunian Kamar Terhadap Pendapatan Sektor Industri Pariwisata Di Kota Surabaya. Jurnal Ekonomi \& Bisnis, 3(2), 687-702. https://doi.org/https://doi.org/10.1234/jeb17.v3i02.2130

Yang, Y., \& Fik, T. (2014). Spatial effects in regional tourism growth. Annals of Tourism Research, 46(October 2017), 144-162. https://doi.org/10.1016/j.annals.2014.03.007

Yergeau, M.E. (2020). Tourism and local welfare: A multilevel analysis in Nepal's protected areas. World Development, $127,104744$. https://doi.org/https://doi.org/10.1016/j.worlddev.2019.104744

Zadeh Bazargani, R.H., \& Kiliç, H. (2021). Tourism competitiveness and tourism sector performance: Empirical insights from new data. Journal of Hospitality and Tourism Management, 46(December 2020), 73-82. https://doi.org/10.1016/j.jhtm.2020.11.011

Article history: Received: 29.01.2021 Revised: 18.06.2021 Accepted: 24.08.2021 Available online: 14.09.2021 